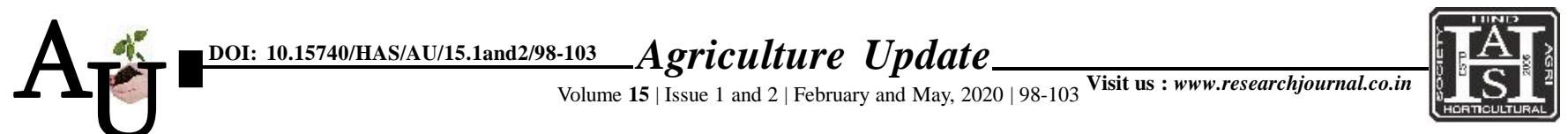

- ISSN-0973-1520

\title{
A REVIF: : Rediscovering potential of dairy co-operatives in Eastern India
}

\section{Kalyan Mandi and Ritu Chakravarty}

Article Chronicle: Received :

01.04.2020;

Accepted :

23.04.2020

KEY Words:

Milk, Production,

Dairy, Farmers

Author for correspondence :

Kalyan Mandi

Dairy Extension

Division, National Dairy

Research Institute,

Karnal (Haryana) India

Email: kalyan.mandi@

gmail.com

See end of the article for

authors' affiliations
SUMMARY : India is the world's largest producer of milk, with 22 per cent of global production. According to NDDB Report 2018-19, India produced 187.7 MT of milk with per capita availability of 394 $\mathrm{g}$ /day. The dairy sector contributes 27 per cent of agriculture GDP and 67 per cent of the total output of the Livestock Sector, thus providing livelihood opportunity to 70 million households. Much of the success of the 'White Revolution' in India is attributed to the co-operative framework of dairy development strategies. After operation flood programme, even though India has stood self-sufficient in milk production, but milk production throughout the states in India is not uniformly distributed and therefore, there are huge demand and supply gap of milk and milk products in few states of Eastern India. Due to lack of proper infrastructure for dairy processing and manufacturing of milk and milk products, poor quality of milch cattle and buffalo breeds and lack of dairy services have posed challenged for dairy development. Less participation of dairy farmers in organized sectors like dairy co-operatives creates instability in the farm income for the dairy farmers. Several studies suggest that farmers' participation in dairy co-operatives has resulted in a significant increase in milk production and productivity and has reduced per-unit cost of milk production thereby enabling them to achieve higher output prices, reduced transaction costs and increased profits. Therefore, dairy co-operatives can play instrumental role in harnessing the potential of the dairy sector in Eastern States of India.

How to cite this article : Mandi, Kalyan and Chakravarty, Ritu (2020). Rediscovering potential of dairy cooperatives in Eastern India. Agric. Update, 15(1 and 2): 98-103; DOI : 10.15740/HAS/AU/15.1and2/98-103. Copyright@ 2020: Hind Agri-Horticultural Society. 